\title{
Strontium barium bismuth tantalate layered perovskites: thin film preparation and ferroelectric characteristics
}

\author{
Chung-Hsin Lu*, Cheng-Yen Wen \\ Department of Chemical Engineering, National Taiwan University, Taipei 106, Taiwan
}

Received 10 May 1999; accepted 4 July 1999

\begin{abstract}
The preparation processes and ferroelectric characteristics of barium cation-incorporated $\mathrm{SrBi}_{2} \mathrm{Ta}_{2} \mathrm{O}_{9}$ thin films have been investigated in this study. Complete solid solutions of $\left(\mathrm{Sr}_{1-x} \mathrm{Ba}_{x}\right) \mathrm{Bi}_{2} \mathrm{Ta}_{2} \mathrm{O}_{9}$ thin films are formed on $\mathrm{Pt} / \mathrm{Ti} / \mathrm{SiO} \mathrm{O}_{2} / \mathrm{Si}$ substrates using a metalorganic decomposition method after annealing at $700^{\circ} \mathrm{C}$. The lattice constant along the c-axis of formed solid solutions monotonously increases with increasing the contents of barium cations. The microstructure and surface morphologies of films significantly vary with the composition. The grain size and the roughness of $\left(\mathrm{Sr}_{1-x} \mathrm{Ba}_{x}\right) \mathrm{Bi}_{2} \mathrm{Ta}_{2} \mathrm{O}_{9}$ films increases as the contents of barium cations increase. All prepared films exhibit ferroelectric characteristics. Increasing the annealing temperature is found to significantly enhance the remanent polarization of prepared thin films. In the formed solid solutions, $\left(\mathrm{Sr}_{0.5} \mathrm{Ba}_{0.5}\right) \mathrm{Bi}_{2} \mathrm{Ta}_{2} \mathrm{O}_{9}$ thin films exhibit the highest remanent polarization. This is attributed to large grain size and preferred a-axis orientation of formed films. (C) 2000 Elsevier Science Ltd. All rights reserved.
\end{abstract}

Keywords: Ferroelectric properties; Films; Microstructure-final; Perovskites; Tantalates; (Sr,Ba) $\mathrm{Bi}_{2} \mathrm{Ta}_{2} \mathrm{O}_{9}$

\section{Introduction}

The layered-structure perovskites, also known as Aurivillius compounds, ${ }^{1-3}$ have recently attracted considerable attention for their application in low-voltage, high-speed ferroelectric random access memory (FeRAM) ${ }^{4,5}$ The chemical formula of Aurivillius compounds is $\left(\mathrm{Bi}_{2} \mathrm{O}_{2}\right)^{2+}\left(\mathrm{A}_{x-1} \mathrm{~B}_{x} \mathrm{O}_{3 x+1}\right)^{2-}$, where $x$ indicates the number of perovskite layers between two $\left(\mathrm{Bi}_{2} \mathrm{O}_{2}\right)^{2+}$ layers, while $\mathrm{A}$ and $\mathrm{B}$ represents cations with low and high valances in the structure. Thin films of several Aurivillius compounds with $x=2$, such as $\mathrm{SrBi}_{2} \mathrm{Ta}_{2} \mathrm{O}_{9}$, $\mathrm{SrBi}_{2} \mathrm{Nb}_{2} \mathrm{O}_{9}$, and $\mathrm{BaBi}_{2} \mathrm{Ta}_{2} \mathrm{O}_{9}$, have been fabricated on the Si-based substrates by different chemical or physical deposition processes. ${ }^{4,6-12}$ The reported results reveal that these thin films exhibit fatigue-free characteristics up to $10^{9}-10^{12}$ switching cycles, low leakage current, long data retention time and stable imprint characteristics. Such excellent fatigue endurance of the layered perovskites makes them superior to the $\mathrm{Pb}(\mathrm{Zr}, \mathrm{Ti}) \mathrm{O}_{3}$ based materials for the application in FeRAM.

The solid-solution system of $\mathrm{SrBi}_{2} \mathrm{Nb}_{2} \mathrm{O}_{9}$ and $\mathrm{BaBi}_{2} \mathrm{Nb}_{2} \mathrm{O}_{9}$ has been studied previously. ${ }^{13,14}$ It is found

* Corresponding author. Tel.: +886-2-3635250; fax: +886-23623040 . that $\mathrm{Ba}^{2+}$ and $\mathrm{Sr}^{2+}$ cations substitute with each other in a solid solution, in which with increasing $\mathrm{Ba}^{2+}$ content, the lattice parameters $a$ and $c$ increase. Besides, the difference between $\mathrm{Sr}^{2+}$ and $\mathrm{Ba}^{2+}$ radii causes a tilting and distortion of the surrounding $\mathrm{NbO}_{6}$ octahedrons. On the other hand, the solid-solution system of $\mathrm{SrBi}_{2} \mathrm{Ta}_{2} \mathrm{O}_{9}$ and $\mathrm{BaBi}_{2} \mathrm{Ta}_{2} \mathrm{O}_{9}$ has not been investigated in detail until now. $\mathrm{BaBi}_{2} \mathrm{Ta}_{2} \mathrm{O}_{9}$ has a similar layered perovskite structure to $\mathrm{SrBi}_{2} \mathrm{Ta}_{2} \mathrm{O}_{9}$, and the formation of solid solutions between these two compounds is feasible because of the slight ionic size difference between $\mathrm{Ba}^{2+}$ and $\mathrm{Sr}^{2+}$ cations. In this study, the $\left(\mathrm{Sr}_{1-x} \mathrm{Ba}_{x}\right)-$ $\mathrm{Bi}_{2} \mathrm{Ta}_{2} \mathrm{O}_{9}$ thin films were prepared on $\mathrm{Pt} / \mathrm{Ti} / \mathrm{SiO}_{2} / \mathrm{Si}$ substrates using a metalorganic decomposition method. The influence of chemical composition and annealing conditions on crystal structure and microstructure of thin films was examined. The effects of the crystal orientation as well as morphology on the ferroelectric properties of thin films were also investigated.

\section{Experimental}

$\left(\mathrm{Sr}_{1-x} \mathrm{Ba}_{x}\right) \mathrm{Bi}_{2} \mathrm{Ta}_{2} \mathrm{O}_{9}$ thin films were fabricated via metalorganic decomposition (MOD) method. Strontium 2-ethylhexanoate $\left[\operatorname{Sr}\left(\mathrm{C}_{8} \mathrm{H}_{15} \mathrm{O}_{2}\right)_{2}\right]$, barium 2-ethyl- 
hexanoate $\left[\mathrm{Ba}\left(\mathrm{C}_{8} \mathrm{H}_{15} \mathrm{O}_{2}\right)_{2}\right]$, bismuth 2-ethylhexanoate $\left[\mathrm{Bi}\left(\mathrm{C}_{8} \mathrm{H}_{15} \mathrm{O}_{2}\right)_{2}\right]$, and tantalum ethoxide $\left[\mathrm{Ta}\left(\mathrm{OC}_{2} \mathrm{H}_{5}\right)_{5}\right]$ were used as starting materials. After thoroughly mixing the above materials in toluene according to the designed composition, the mixed precursors were spin-coated onto $\mathrm{Pt} / \mathrm{Ti} / \mathrm{SiO}_{2} / \mathrm{Si}$ substrates. The as-deposited films were baked on the hot plate at $150^{\circ} \mathrm{C}$ to remove the solvent, and were subsequently pyrolyzed at $400^{\circ} \mathrm{C}$ to burn out the organic species. The pyrolyzed films were then annealed at 700 and $750^{\circ} \mathrm{C}$ for $2 \mathrm{~h}$ in flowing oxygen for enhancing crystallinity of films. Crystalline phases of the annealed films were identified by X-ray diffraction (XRD) analysis. The surface morphologies were examined by scanning electron microscopy (SEM) and atomic force microscopy (AFM) under tapping mode with amplitude modulation. For measuring the electric properties of prepared thin films, the top $\mathrm{Pt}$ electrodes were deposited on thin films through a mask by $\mathrm{rf}$ magnetron sputtering, and annealed at $400^{\circ} \mathrm{C}$ for improving the adhesion between the top electrodes and the films. The ferroelectric hysteresis measurement were conducted on films in metal-ferroelectric-metal (MFM) configuration using a standardized ferroelectricity test system in the virtual ground.

\section{Results and discussion}

\subsection{Preparation and crystal structure of $\left(S r_{1-\mathrm{x}} B a_{\mathrm{x}}\right)$ - $\mathrm{Bi}_{2} \mathrm{Ta}_{2} \mathrm{O}_{9}$ thin films}

Fig. 1 illustrates the XRD patterns of $700^{\circ} \mathrm{C}$-annealed $\left(\mathrm{Sr}_{1-x} \mathrm{Ba}_{x}\right) \mathrm{Bi}_{2} \mathrm{Ta}_{2} \mathrm{O}_{9}$ films. It is observed that thin films

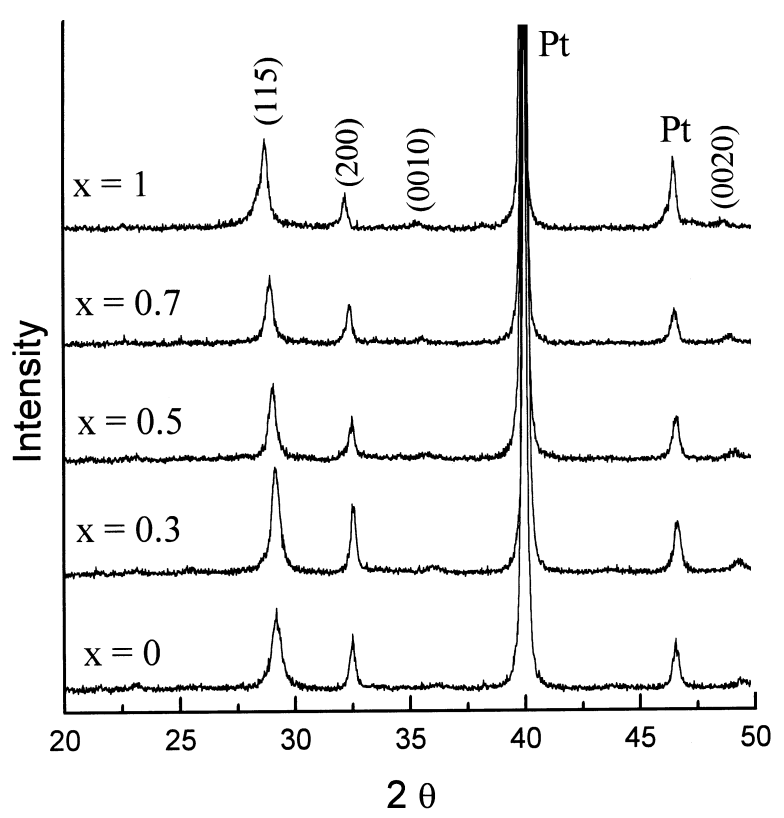

Fig. 1. X-ray diffraction patterns of $\left(\mathrm{Sr}_{1-x} \mathrm{Ba}_{x}\right) \mathrm{Bi}_{2} \mathrm{Ta}_{2} \mathrm{O}_{9}$ thin films annealed at $700^{\circ} \mathrm{C}$. with the similar monophasic layered-perovskite structure are formed regardless of various contents of barium cations. With an increase in $x$, the peaks (115), (020), (0010), and (0020) are slightly shifted to the direction of low diffraction angle. This slight shifting is caused by gradual distortion of the unit cell. The above XRD results confirm that complete solid solutions of $\mathrm{SrBi}_{2} \mathrm{Ta}_{2} \mathrm{O}_{9}$ and $\mathrm{BaBi}_{2} \mathrm{Ta}_{2} \mathrm{O}_{9}$ are formed. The similar ionic radii of strontium and barium cations and the same orthorhombic crystal structure of $\mathrm{SrBi}_{2} \mathrm{Ta}_{2} \mathrm{O}_{9}$ and $\mathrm{BaBi}_{2} \mathrm{Ta}_{2} \mathrm{O}_{9}$ makes strontium and barium cation to substitute with each other without significant variation in layered perovskite structure.

The variation of lattice parameters $a, b$, and $c$ as a function of the $x$ value of $\left(\mathrm{Sr}_{1-x} \mathrm{Ba}_{x}\right) \mathrm{Bi}_{2} \mathrm{Ta}_{2} \mathrm{O}_{9}$ solid solution thin films is depicted in Fig. 2. As shown in this figure, the value of lattice parameter $c$ increases almost linearly with the increase in $x$. This indicates a progressive distortion occurs in the $c$-axis direction when strontium cations are replaced by barium cations. The size of $\mathrm{Ba}^{2+}(1.34 \AA)$ is larger than that of $\mathrm{Sr}^{2+}(1.13$ $\AA$ ), thus the introduction of $\mathrm{Ba}^{2+}$ into $\mathrm{SrBi}_{2} \mathrm{Ta}_{2} \mathrm{O}_{9}$ causes the expansion of lattices. On the other hand, the values of $a$ and $b$ axes do not linearly vary with $x$. When $x$ is less than 0.5 , the lattice parameters $a$ and $b$ are nearly the same as those of $\mathrm{SrBi}_{2} \mathrm{Ta}_{2} \mathrm{O}_{9}(x=0)$. At $x>0.5$, both the values of $a$ and $b$ increase with an increase in $x$. The structure of Aurivillius compound $\mathrm{SrBi}_{2} \mathrm{Ta}_{2} \mathrm{O}_{9}$ is composed of two perovskite-like units between $\left(\mathrm{Bi}_{2} \mathrm{O}_{2}\right)^{2+}$ layers along the orthorhombic $c$ axis. The directions of $a$ and $b$ axes are parallel to the

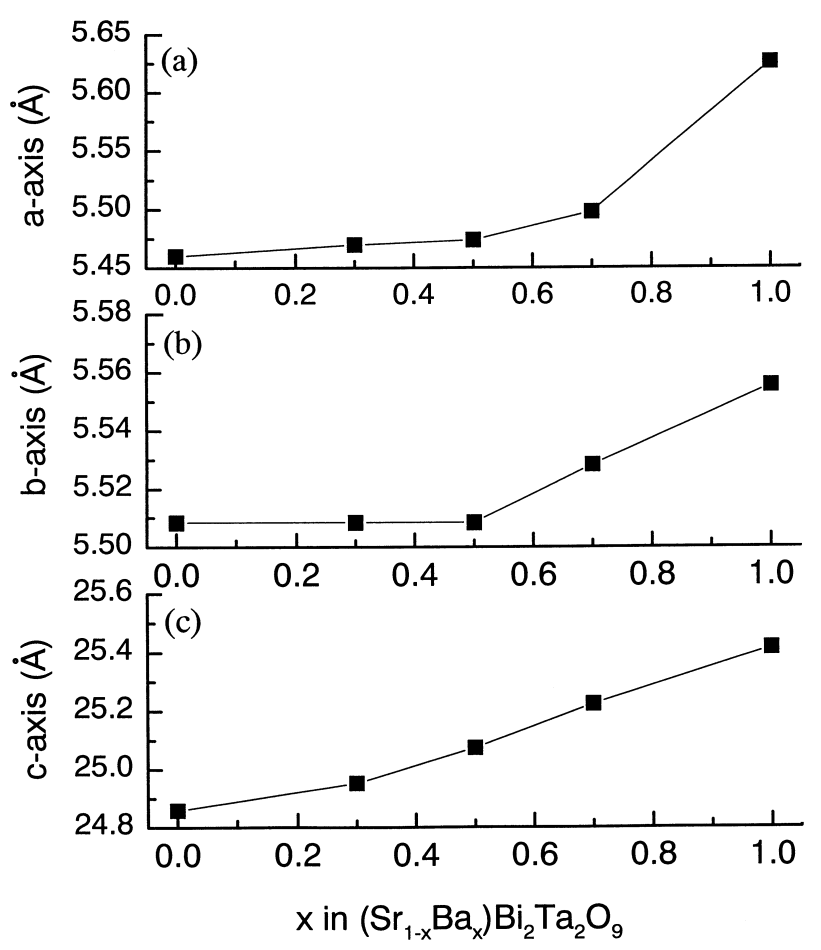

Fig. 2. Lattice parameters of $\left(\mathrm{Sr}_{1-x} \mathrm{Ba}_{x}\right) \mathrm{Bi}_{2} \mathrm{Ta}_{2} \mathrm{O}_{9}$ thin films. 
$\left(\mathrm{Bi}_{2} \mathrm{O}_{2}\right)^{2+}$ layers. It is suggested that when the doping amount of barium cations in $\mathrm{SrBi}_{2} \mathrm{Ta}_{2} \mathrm{O}_{9}$ is low, the expansion of the unit cell in the direction of $a$ and $b$ axes will be annihilated by the closed packed $\left(\mathrm{Bi}_{2} \mathrm{O}_{2}\right)^{2+}$ layer.

XRD patterns for the $750^{\circ} \mathrm{C}$-annealed films are similar to $700^{\circ} \mathrm{C}$-annealed films, except that the diffraction intensity of films increases, implying better crystallinity of films. It is revealed from these results that $\left(\mathrm{Sr}_{1-x} \mathrm{Ba}_{x}\right)$ $\mathrm{Bi}_{2} \mathrm{Ta}_{2} \mathrm{O}_{9}$ solid solutions are stable after annealing at $750^{\circ} \mathrm{C}$. However, an unknown phase is found to exist in $\mathrm{BaBi}_{2} \mathrm{Ta}_{2} \mathrm{O}_{9}$ films. The appearance of this unknown phase is believed to be caused by the interaction of the titanium diffusing from the bottom electrode with the constitutes of the $\mathrm{BaBi}_{2} \mathrm{Ta}_{2} \mathrm{O}_{9}$ thin film. ${ }^{11}$

\subsection{Microstructures of $\left(\mathrm{Sr}_{1-\mathrm{x}} B \mathrm{Ba}_{\mathrm{x}}\right) \mathrm{Bi}_{2} \mathrm{Ta}_{2} \mathrm{O}_{9}$ thin films}

The SEM micrographs of $700^{\circ} \mathrm{C}$-annealed $\left(\mathrm{Sr}_{1-x} \mathrm{Ba}_{x}\right)$ $\mathrm{Bi}_{2} \mathrm{Ta}_{2} \mathrm{O}_{9}$ thin films fabricated on $\mathrm{Pt} / \mathrm{Ti} / \mathrm{SiO}_{2} / \mathrm{Si}$ are shown in Fig. 3. All films have uniform and dense microstructures. At $x=0$ and 0.3 , no specific feature can be identified as the grain size of films is too small. At $x \geqslant 0.5$, the film is found to consist of spheroidal grains. The atomic force micrographs of $700^{\circ} \mathrm{C}$-annealed $\left(\mathrm{Sr}_{1-x} \mathrm{Ba}_{x}\right) \mathrm{Bi}_{2} \mathrm{Ta}_{2} \mathrm{O}_{9}$ thin films are shown in Fig. 4. At $x=0$ and 0.3 the films exhibit rather smooth surface, while at $x \geqslant 0.5$ films have particulate feature and the surface of films become rough. The surface roughness of $\left(\mathrm{Sr}_{1-x} \mathrm{Ba}_{x}\right) \mathrm{Bi}_{2} \mathrm{Ta}_{2} \mathrm{O}_{9}$ thin films is calculated and summarized in Table 1. It is observed that the surface roughness of films monotonously increases with an increase in $x$. The SEM micrographs of $750^{\circ} \mathrm{C}$-annealed $\left(\mathrm{Sr}_{1-x} \mathrm{Ba}_{x}\right) \mathrm{Bi}_{2^{-}}$ $\mathrm{Ta}_{2} \mathrm{O}_{9}$ thin films are shown in Fig. 5. In comparison with the $700^{\circ} \mathrm{C}$-annealed films, $750^{\circ} \mathrm{C}$-annealed films experience significant grain growth. All films are found to contain spheroidal grains, except that $\mathrm{BaBi}_{2} \mathrm{Ta}_{2} \mathrm{O}_{9}(x=1)$ films comprise rod-like grains, reflecting its idiomorphic morphology of orthorhombic crystal structure.

The grain sizes of $\left(\mathrm{Sr}_{1-x} \mathrm{Ba}_{x}\right) \mathrm{Bi}_{2} \mathrm{Ta}_{2} \mathrm{O}_{9}$ thin films annealed at 700 and $750^{\circ} \mathrm{C}$ are listed in Table 2. Due to limitation of resolution in SEM, the grain size of the $700^{\circ} \mathrm{C}$-annealed films are analyzed by AFM. Table 2 manifests that at the same composition the grain size of thin films annealed at $750^{\circ} \mathrm{C}$ is larger than that annealed at $700^{\circ} \mathrm{C}$. Furthermore, the grain size of films increases with an increase in $x$ for either 700 or $750^{\circ} \mathrm{C}$-annealed $\left(\mathrm{Sr}_{1-x} \mathrm{Ba}_{x}\right) \mathrm{Bi}_{2} \mathrm{Ta}_{2} \mathrm{O}_{9}$ films. It is revealed that the microstructure of films and morphology of grains strongly depend on the composition of films and annealing conditions.

\subsection{Ferroelectric characteristics of $\left(\mathrm{Sr}_{1-\mathrm{x}} \mathrm{Ba}_{\mathrm{x}}\right) \mathrm{Bi}_{2} \mathrm{Ta}_{2} \mathrm{O}_{9}$ thin films}

The ferroelectric properties of $\left(\mathrm{Sr}_{1-x} \mathrm{Ba}_{x}\right) \mathrm{Bi}_{2} \mathrm{Ta}_{2} \mathrm{O}_{9}$ thin films annealed at $700^{\circ} \mathrm{C}$ are shown in Fig. 6. It is

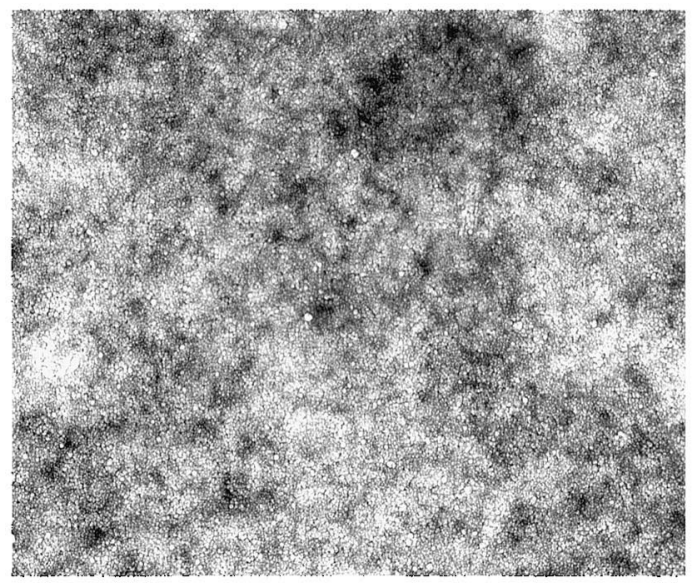

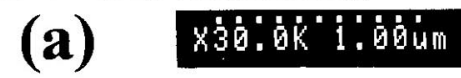

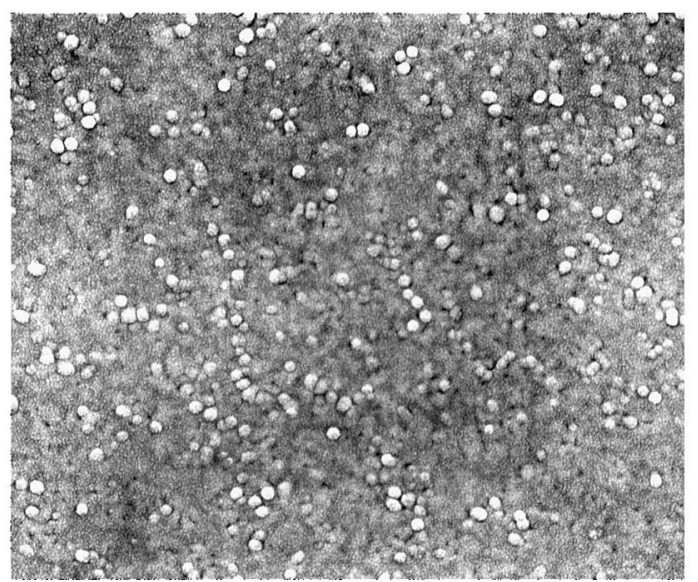

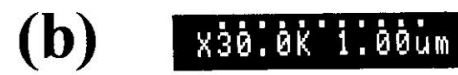

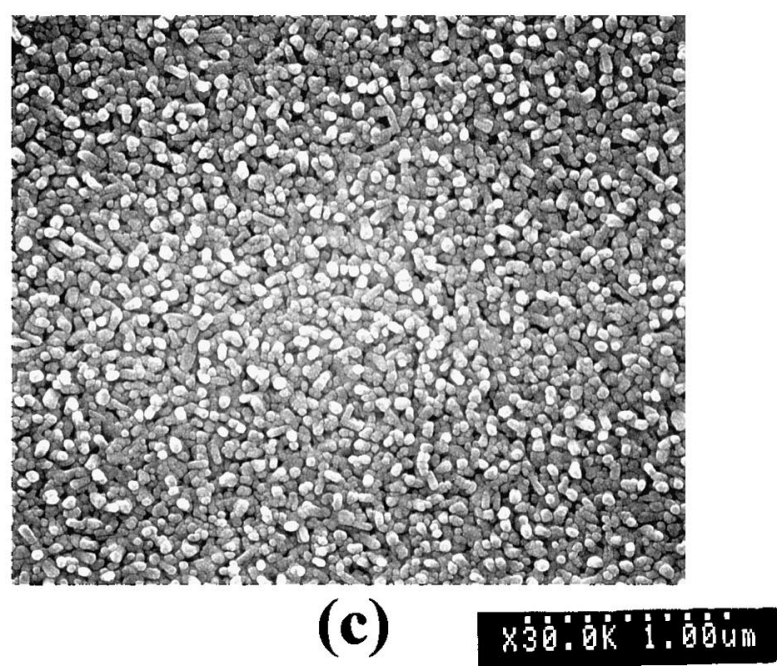

Fig. 3. Scanning electron micrographs of $\left(\mathrm{Sr}_{1-x} \mathrm{Ba}_{x}\right) \mathrm{Bi}_{2} \mathrm{Ta}_{2} \mathrm{O}_{9}$ thin films annealed at $700^{\circ} \mathrm{C}$. (a) $x=0$ (b) $x=0.5$, and (c) $x=0.7$.

found that saturated polarization-electric field curves are obtained in all films, revealing that all prepared films exhibit ferroelectric characteristics. The relation between the remanent polarization $\left(2 P_{r}\right)$ as well as the 


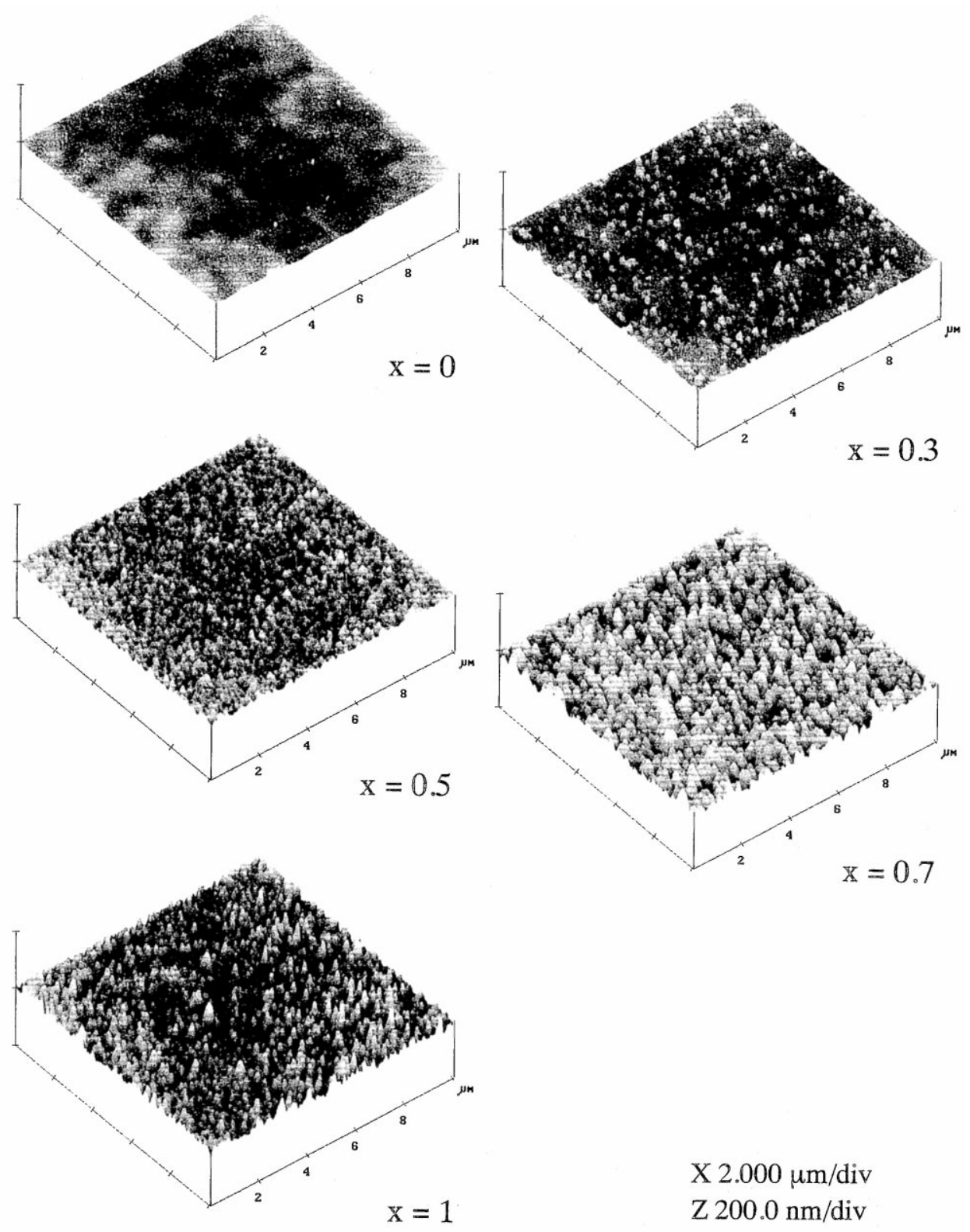

Fig. 4. Atomic force micrographs of $\left(\mathrm{Sr}_{1-x} \mathrm{Ba}_{x}\right) \mathrm{Bi}_{2} \mathrm{Ta}_{2} \mathrm{O}_{9}$ thin films annealed at $700^{\circ} \mathrm{C}$.

Table 1

Surface roughness of $\left(\mathrm{Sr}_{1-x} \mathrm{Ba}_{x}\right) \mathrm{Bi}_{2} \mathrm{Ta}_{2} \mathrm{O}_{9}$ thin films

\begin{tabular}{llllll}
\hline Composition & $x=0$ & $x=0.3$ & $x=0.5$ & $x=0.7$ & $x=1$ \\
\hline Roughness $(\mathrm{nm})$ & 2.6 & 2.9 & 4.7 & 8.6 & 9.7 \\
\hline
\end{tabular}

coercive field $\left(2 E_{c}\right)$ of $\left(\mathrm{Sr}_{1-x} \mathrm{Ba}_{x}\right) \mathrm{Bi}_{2} \mathrm{Ta}_{2} \mathrm{O}_{9}$ thin films and the value of $x$ is plotted in Fig. 7. The values of $2 P_{r}$ of $\mathrm{SrBi}_{2} \mathrm{Ta}_{2} \mathrm{O}_{9}(x=0)$ and $\mathrm{BaBi}_{2} \mathrm{Ta}_{2} \mathrm{O}_{9}(x=1)$ are 1.4 and $1.9 \mu \mathrm{C} / \mathrm{cm}^{2}$, respectively. However, the solid solutions of the above two compounds have higher remanent polarization than the two end members. A maximum value of $2 P_{r}$ is attained at $x=0.5$. Furthermore, the
$\left(\mathrm{Sr}_{1-x} \mathrm{Ba}_{x}\right) \mathrm{Bi}_{2} \mathrm{Ta}_{2} \mathrm{O}_{9}$ solid solutions also have higher coercive fields than the end members.

Fig. 8 illustrates saturated polarization-electric field curves of the $750^{\circ} \mathrm{C}$-annealed $\left(\mathrm{Sr}_{1-x} \mathrm{Ba}_{x}\right) \mathrm{Bi}_{2} \mathrm{Ta}_{2} \mathrm{O}_{9}$ films. The values of the remanent polarization as well as the coercive field of $750^{\circ} \mathrm{C}$-annealed films are plotted against the value of $x$ in Fig. 9. In comparison of Fig. 7 with Fig. 9, it is revealed that $750^{\circ} \mathrm{C}$-annealed films have higher remanent polarization and lower coercive field than $700^{\circ} \mathrm{C}$ annealed films. The improvement on the ferroelectric characteristics by high-temperature annealing is attributed to the enhanced crystallinity and larger grain size. ${ }^{15,16}$ In addition, the films at $x=0.5$ exhibit a maximum value of $2 P_{r}\left(14.1 \mu \mathrm{C} / \mathrm{cm}^{2}\right)$, which is much 


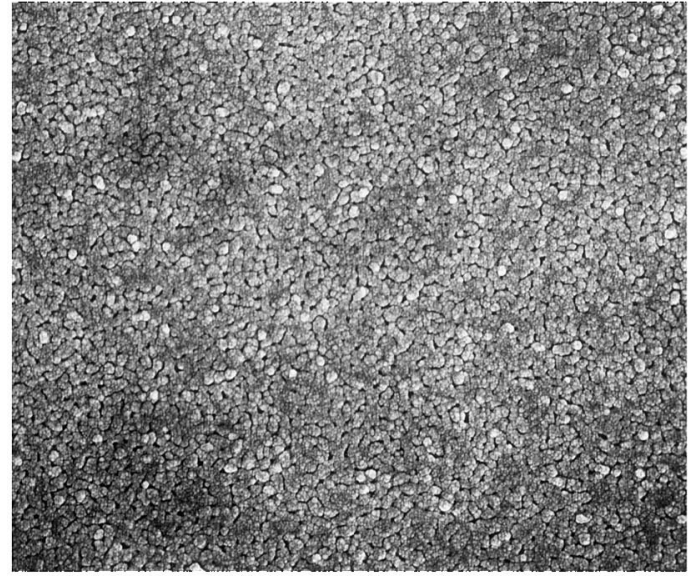

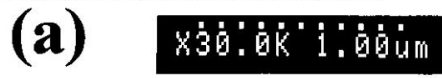

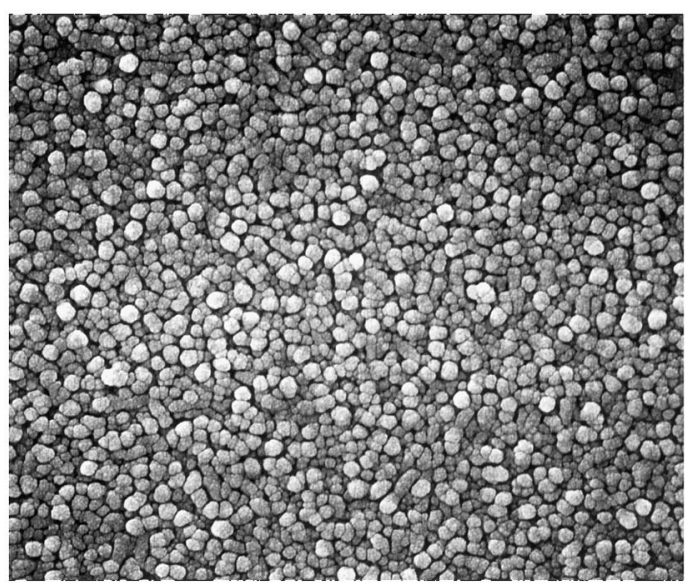

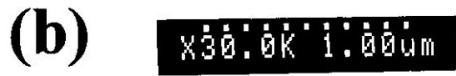

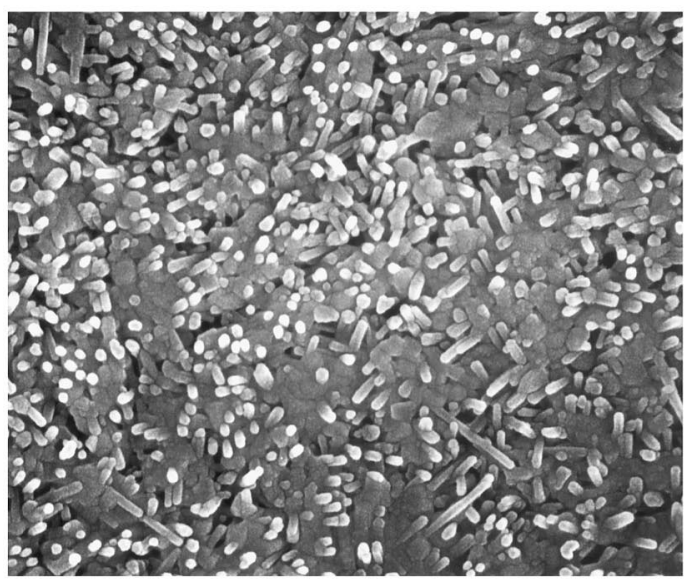

(c)

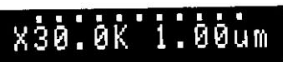

Fig. 5. Scanning electron micrographs of $\left(\mathrm{Sr}_{1-x} \mathrm{Ba}_{x}\right) \mathrm{Bi}_{2} \mathrm{Ta}_{2} \mathrm{O}_{9}$ thin films annealed at $750^{\circ} \mathrm{C}$. (a) $x=0$, (b) $x=0.5$, and (c) $x=1.0$.

higher than that of pure $\mathrm{SrBi}_{2} \mathrm{Ta}_{2} \mathrm{O}_{9}\left(2 P_{r}=3.7 \mu \mathrm{C} /\right.$ $\left.\mathrm{cm}^{2}\right)$. The coercive field $\left(2 E_{c}\right)$ of $\left(\mathrm{Sr}_{1-x} \mathrm{Ba}_{x}\right) \mathrm{Bi}_{2} \mathrm{Ta}_{2} \mathrm{O}_{9}$ $(x=0.3-0.7)$ is slightly higher than that of pure $\mathrm{SrBi}_{2}-\mathrm{Ta}_{2} \mathrm{O}_{9}(x=0)$. However, for $\mathrm{BaBi}_{2} \mathrm{Ta}_{2} \mathrm{O}_{9}(x=1)$,
Table 2

Grain size of $\left(\mathrm{Sr}_{1-x} \mathrm{Ba}_{x}\right) \mathrm{Bi}_{2} \mathrm{Ta}_{2} \mathrm{O}_{9}$ thin films

\begin{tabular}{llllll}
\hline Composition & $x=0$ & $x=0.3$ & $x=0.5$ & $x=0.7$ & $x=1$ \\
\hline Grain size at $700^{\circ} \mathrm{C}(\mu \mathrm{m})$ & 0.01 & 0.02 & 0.02 & 0.04 & 0.03 \\
Grain size at $750^{\circ} \mathrm{C}(\mu \mathrm{m})$ & 0.06 & 0.07 & 0.08 & 0.09 & 0.20 (length) \\
& & & & & 0.04 (width) \\
\hline
\end{tabular}

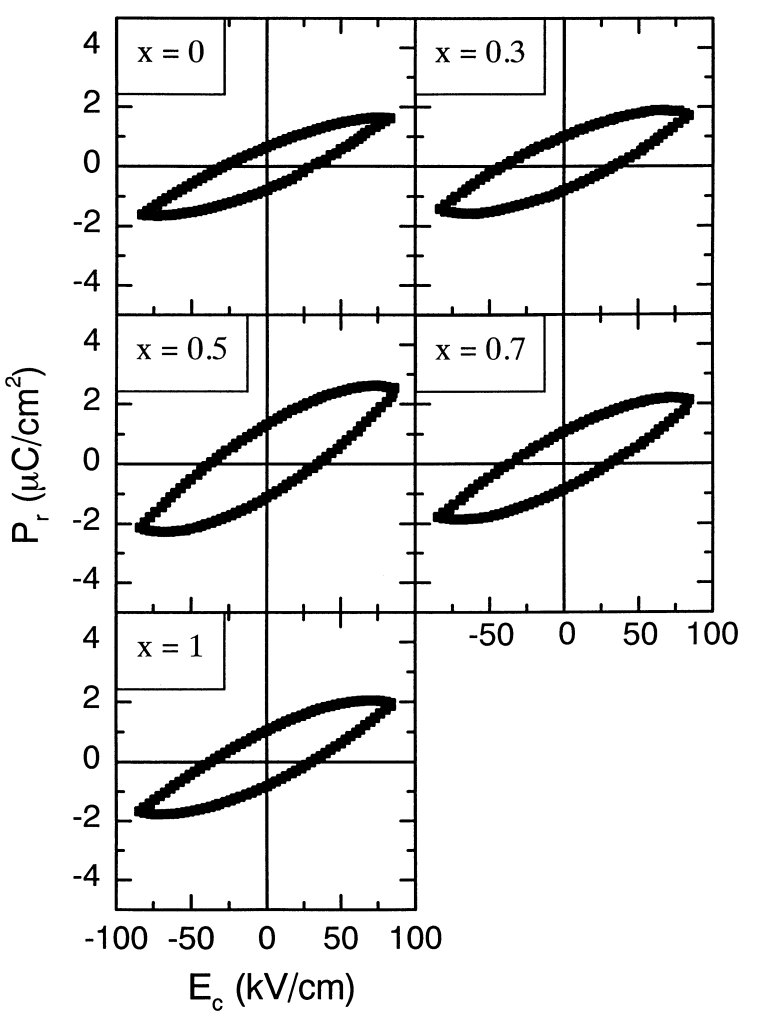

Fig. 6. Polarization electric field hysteresis curves of $\left(\mathrm{Sr}_{1-x} \mathrm{Ba}_{x}\right)$ $\mathrm{Bi}_{2} \mathrm{Ta}_{2} \mathrm{O}_{9}$ thin films annealed at $700^{\circ} \mathrm{C}$.

an abnormally high coercive field is observed. This probably is ascribed to the existence of the unknown phase in $\mathrm{BaBi}_{2} \mathrm{Ta}_{2} \mathrm{O}_{9}$ films, ${ }^{11}$ which hampers the switching process of polarization.

For the $\mathrm{SrBi}_{2} \mathrm{Ta}_{2} \mathrm{O}_{9}$-based systems, it is well known that increasing the grain size of film improves the remanent polarization. ${ }^{17,18}$ In the present study (as shown in Table 2), the grain size of $\left(\mathrm{Sr}_{1-x} \mathrm{Ba}_{x}\right) \mathrm{Bi}_{2} \mathrm{Ta}_{2} \mathrm{O}_{9}$ films increases with an increase in $x$; however, the remanent polarization of prepared films does not monotonously increase with increasing $x$. Therefore, besides the effect of grain size, other effects to account for variation in remanent polarization have to be considered. For bismuth layered perovskites, usually a-axis oriented films exhibit larger remanent polarization and larger coercive field than $c$-axis oriented films. ${ }^{19}$ For quantifying the degree of $a$-axis preferred orientation 
(D) of $\left(\mathrm{Sr}_{1-x} \mathrm{Ba}_{x}\right) \mathrm{Bi}_{2} \mathrm{Ta}_{2} \mathrm{O}_{9}$ thin films, the following equation is used:

$D=\left(I_{(200)} / I_{(115)}\right)_{\text {Film }} /\left(I_{(200)} / I_{(115)}\right)_{\text {Powder }}$

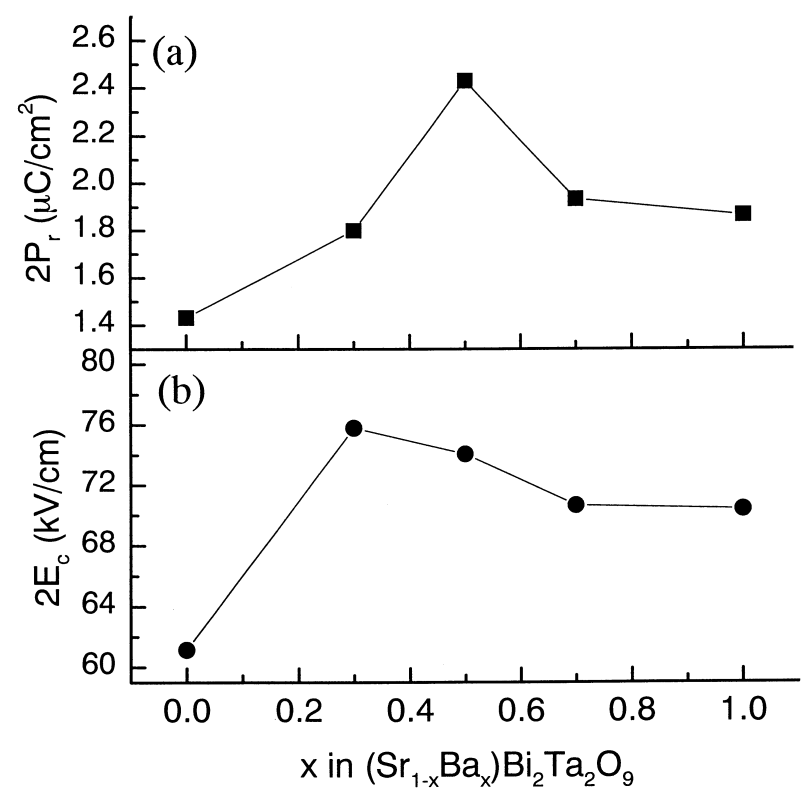

Fig. 7. (a) Remanent polarization and (b) coercive field of $\left(\mathrm{Sr}_{1-x} \mathrm{Ba}_{x}\right)$ $\mathrm{Bi}_{2} \mathrm{Ta}_{2} \mathrm{O}_{9}$ thin films annealed at $700^{\circ} \mathrm{C}$.

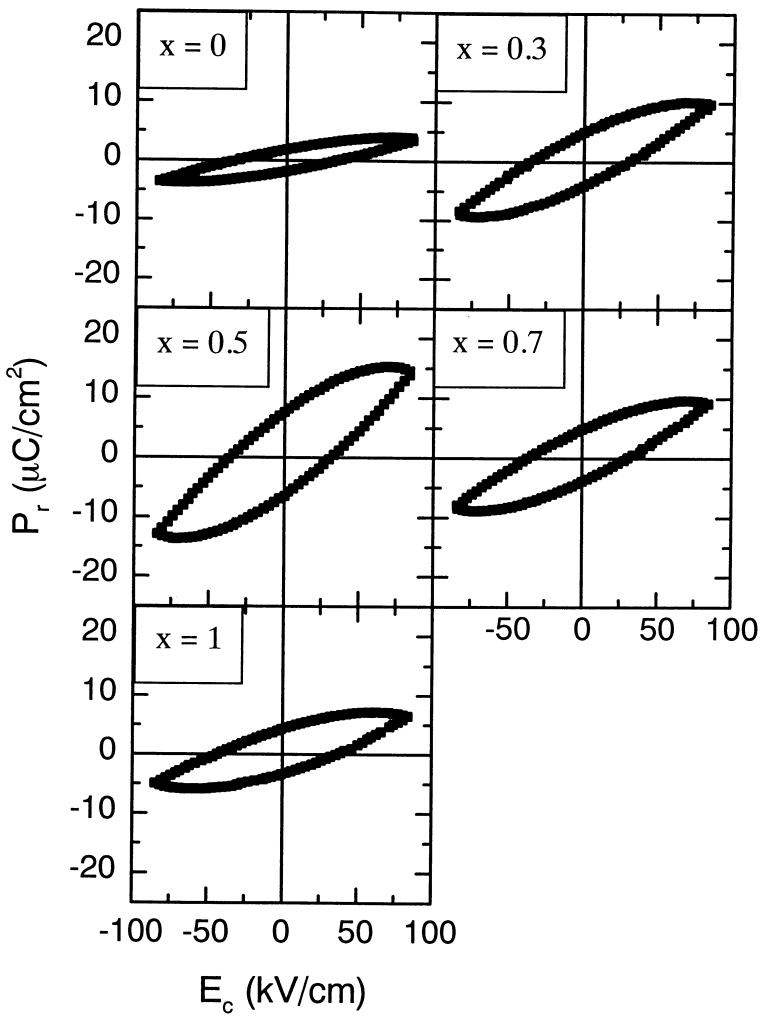

Fig. 8. Polarization electric field hysteresis curves of $\left(\mathrm{Sr}_{1-x} \mathrm{Ba}_{x}\right) \mathrm{Bi}_{2-}$ $\mathrm{Ta}_{2} \mathrm{O}_{9}$ thin films annealed at $750^{\circ} \mathrm{C}$. where $\left(I_{(200)} / I_{(115)}\right)_{\text {Film }} /$ and $\left(I_{(200)} / I_{(115)}\right)_{\text {Powder }}$ are the ratio of diffraction intensity of the (200) plane to the dominant (115) plane of films and polycrystalline powders, respectively, for each composition. The value of $I_{(200)} / I_{(115)}$ of polycrystalline powders is taken as a reference. For random oriented films, the value of $D$ is equal to unity; while the films have certain preferred orientation in $a$-axis, the value of $D$ is larger than unity. The degrees of $a$-axis preferred orientation for each composition are listed in Table 3. The high temperature annealing seems to reduce the $D$ value. However, for either 700 or $750^{\circ} \mathrm{C}$ annealed films, the solid solutions of $\left(\mathrm{Sr}_{1-x} \mathrm{Ba}_{x}\right) \mathrm{Bi}_{2} \mathrm{Ta}_{2} \mathrm{O}_{9}$ exhibit a larger $D$ value than both end members. At $x=0.5,\left(\mathrm{Sr}_{0.5} \mathrm{Ba}_{0.5}\right) \mathrm{Bi}_{2}$ $\mathrm{Ta}_{2} \mathrm{O}_{9}$ film has a maximum $D$ value. It is worthy to note that the maximum remanent polarization occurs at the same value of $x$ as shown in Figs. 7-9. Consequently, the improvement on the remanent polarization of $\left(\mathrm{Sr}_{1-x} \mathrm{Ba}_{x}\right) \mathrm{Bi}_{2} \mathrm{Ta}_{2} \mathrm{O}_{9}$ thin films results from not only the grain growth, but also $a$-axis preferred orientation of films.

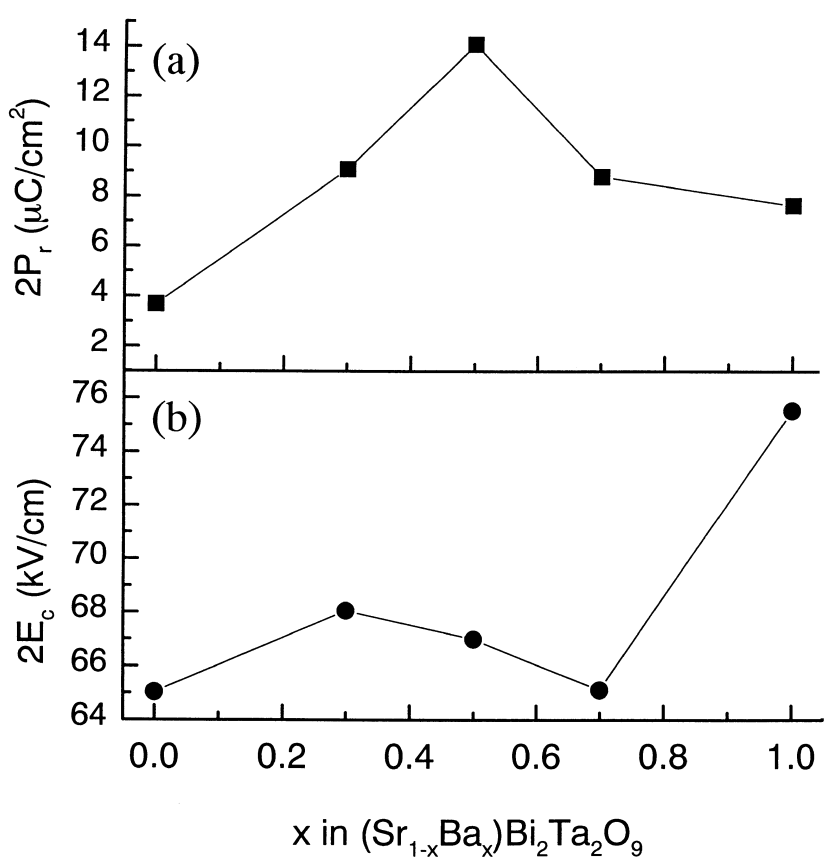

Fig. 9. (a) Remanent polarization and (b) coercive field of $\left(\mathrm{Sr}_{1-x} \mathrm{Ba}_{x}\right)$ $\mathrm{Bi}_{2} \mathrm{Ta}_{2} \mathrm{O}_{9}$ thin films annealed at $750^{\circ} \mathrm{C}$.

Table 3

Degree of $a$-axis preferred orientation $(D)$ of $\left(\mathrm{Sr}_{1-x} \mathrm{Ba}_{\mathrm{x}}\right) \mathrm{Bi}_{2} \mathrm{Ta}_{2} \mathrm{O}_{9}$ thin films

\begin{tabular}{llllll}
\hline Composition & $x=0$ & $x=0.3$ & $x=0.5$ & $x=0.7$ & $x=1$ \\
\hline$D$ at $700^{\circ} \mathrm{C}$ & 1.34 & 1.42 & 1.59 & 1.33 & 1.09 \\
$D$ at $750^{\circ} \mathrm{C}$ & 1.10 & 1.23 & 1.29 & 1.24 & 0.69
\end{tabular}




\section{Conclusions}

The complete solid solutions of $\mathrm{BaBi}_{2} \mathrm{Ta}_{2} \mathrm{O}_{9}-\mathrm{SrBi}_{2}-$ $\mathrm{Ta}_{2} \mathrm{O}_{9}$ thin films are synthesized on $\mathrm{Pt} / \mathrm{Ti} / \mathrm{SiO}_{2} / \mathrm{Si}$ substrates by metalorganic decomposition method after annealing at $700^{\circ} \mathrm{C}$. The lattice constant along the $c$-axis of the formed $\left(\mathrm{Sr}_{1-x} \mathrm{Ba}_{x}\right) \mathrm{Bi}_{2} \mathrm{Ta}_{2} \mathrm{O}_{9}$ solid solutions monotonously increases with increasing the contents of barium cations. The microstructure and surface morphologies of prepared films significantly depend on the composition of films. The grain size as well as the roughness of formed films increases with increasing the contents of barium cations. As for the ferroelectric characteristics, raising the annealing temperature markedly enhances the remanent polarization of prepared thin films. Furthermore, in the formed solid solutions, $\left(\mathrm{Sr}_{0.5} \mathrm{Ba}_{0.5}\right) \mathrm{Bi}_{2} \mathrm{Ta}_{2} \mathrm{O}_{9}$ thin films are found to exhibit the highest remanent polarization, which is ascribed to large grain size and preferred a-axis orientation of formed films.

\section{References}

1. Aurivillius, B., Mixed bismuth oxides with layer lattices I. The structure Type of $\mathrm{CaNb}_{2} \mathrm{Bi}_{2} \mathrm{O}_{9}$. Arkiv for Kemi, 1949, 1(54), 463 480 .

2. Aurivillius, B., Mixed bismuth oxides with layer lattices II. Structure type of $\mathrm{Bi}_{4} \mathrm{Ti}_{3} \mathrm{O}_{12}$. Arkiv for Kemi, 1949, 1(58), 499-512.

3. Aurivillius, B., Mixed bismuth oxides with layer lattices III. Structure Type of $\mathrm{BaBi}_{4} \mathrm{Ti}_{4} \mathrm{O}_{15}$. Arkiv for Kemi, 1950, 2(37), 519527.

4. Araujo, C. A., Paz de Cuchiaro, J. D., Scott, M. C. and McMillan, L. D., Layered superlattice material applications. Int. Patent Appl. No. WO93/12542, June 24, 1993.

5. Jones, R. E. Jr., Maniar, P. D., Moazzami, R., Zurcher, P., Witowski, J. Z., Lii, Y. T., Chu, P. and Gillespie, S. J., Ferroelectric non-volatile memories for low-voltage, low-power applications. Thin Solid Films, 1995, 270(1-2), 584-588.

6. Joshi, P. C., Ryu, S. O., Zhang, X. and Desu, S. B., Properties of ferroelectric $\mathrm{SrBi}_{2} \mathrm{Ta}_{2} \mathrm{O}_{9}$ thin films prepared by a modified metalorganic solution deposition technique. Appl. Phys. Lett., 1997, 70(9), 1080-1082.

7. Park, S. S., Yang, C. H., Yoon, S. G., Ahn, J. H. and Kim, H. G., Characterization of ferroelectric $\mathrm{SrBi}_{2} \mathrm{Ta}_{2} \mathrm{O}_{9}$ thin films deposited by a radio frequency magnetron sputtering technique. J. Electrochem. Soc., 1997, 144(8), 2855-2858.

8. Dat, R., Lee, J. K., Auciello, O. and Kingon, A. I., Pulsed laser ablation synthesis and characterization of layered $\mathrm{Pt} / \mathrm{SrBi}_{2} \mathrm{Ta}_{2} \mathrm{O}_{9} / \mathrm{Pt}$ ferroelectric capacitors with practically no polarization fatigue. Appl. Phys. Lett., 1995, 67(4), 572-574.

9. Zhu, Y., Desu, S. B., Li, T. and Ramanathan, S., $\mathrm{SrBi}_{2} \mathrm{Ta}_{2} \mathrm{O}_{9}$ thin films made by liquid source metal-organic chemical vapor deposition. J. Mater. Res., 1997, 12(3), 783-792.

10. Desu, S. B. and Vijay, D. P., c-Axis oriented ferroelectric $\mathrm{SrBi}_{2}\left(\mathrm{Ta}_{x} \mathrm{Nb}_{2-x}\right) \mathrm{O}_{9}$ thin films. Mater. Sci. Eng., 1995, B32(1-2), 83-88.

11. Lu, C. H. and Wen, C. Y., New non-fatigue ferroelectric thin films of barium bismuth tantalate. Mater. Lett., 1999, 38(4), 278-282.

12. Lu, C. H. and Fang, B. K., Secondary phase formation and microstructural development in the interaction between $\mathrm{SrBi}_{2} \mathrm{Ta}_{2} \mathrm{O}_{9}$ films and $\mathrm{Pt} / \mathrm{Ti} / \mathrm{SiO}_{2} / \mathrm{Si}$ substrates. J. Mater. Res., 1997, 12(8), 2104-2110.

13. Wachsmuth, B., Zschech, E., Thomas, N. W., Brodie, S. G., Gurman, S. J., Baker, S. and Bayliss, S. C., Structure model of aurivillius compounds: an EXAFS study. Phys. Stat. Sol. (a), 1993, 135(1), 59-71.

14. Subbarao, E. C., Crystal chemistry of mixed bismuth oxides with layer-type structure. J. Am. Ceram. Soc., 1962, 45(4), 166-169.

15. Arlt, G., Hennings, D. and de With, D., Dielectric properties of fine-grained barium titanate ceramics. J. Appl. Phys., 1985, 58(4), $1619-1625$.

16. Ren, S. B., Lu, C. J., Liu, J. S., Shen, H. M. and Wang, Y. N., Size-related ferroelectric-domain-structure transition in a polycrystalline $\mathrm{PbTiO}_{3}$ thin film. Phys. Rev. B, 1996, 54(20), 337-340.

17. Desu, S. B., Joshi, P. C., Zhang, X. and Ryu, S. O., Thin films of layered-structure $(1-x) \mathrm{SrBi}_{2} \mathrm{Ta}_{2} \mathrm{O}_{9}-x \mathrm{Bi}_{3} \mathrm{Ti}\left(\mathrm{Ta}_{1-y} \mathrm{Nb}_{y}\right) \mathrm{O}_{9} \quad$ solid solution for ferroelectric random access memory devices. Appl. Phys. Lett., 1997, 71(8), 1041-1043.

18. Nagata, M., Vijay, D. P., Zhang, X. and Desu, S. B., Formation and properties of $\mathrm{SrBi}_{2} \mathrm{Ta}_{2} \mathrm{O}_{9}$ thin films. Phys. Stat. Sol. (a), 1996, 157(1), 75-82.

19. Cummins, S. E. and Cross, L. E., Electrical and optical properties of ferroelectric $\mathrm{Bi}_{4} \mathrm{Ti}_{3} \mathrm{O}_{12}$ single crystals. J. Appl. Phys., 1968, 39(5), 2268-2274. 